\title{
A model for resource allocation using operational knowledge assets
}

\author{
Andreas N. Andreou \\ Institute for Knowledge and Innovation, School of Engineering and Applied Science, \\ Department of Engineering Management and Systems Engineering, \\ George Washington University, Washington, District of Columbia, USA, and \\ Nick Bontis \\ DeGroote School of Business, McMaster University, Hamilton, Canada
}

\begin{abstract}
Purpose - The paper seeks to develop a business model that shows the impact of operational knowledge assets on intellectual capital (IC) components and business performance and use the model to show how knowledge assets can be prioritized in driving resource allocation decisions.

Design/methodology/approach - Quantitative data were collected from 84 high-tech federal contractors in the Washington DC metro area. Respondents in the target population were middle-level and operations managers of business sectors holding positions as presidents, vice-presidents, directors, engineering managers, operations managers, and analysts. Partial least squares (PLS) analysis was performed to develop a structural model between operational knowledge assets and IC components that maximizes explained variance for business performance. Operational assets were specified as formative constructs and IC and business performance were specified as reflective constructs.

Findings - A parsimonious conceptually sound model with significant measured variables and path coefficients was developed that explains almost 40 percent of the variance in business performance. The model shows both the interrelationships between the IC components that drive performance and the operational assets as levers for each IC component, respectively.

Research limitations/implications - The scope of the study was focused on the high-tech federal contractors in the USA. However, the model can be applied and tested in different industry sectors. This would provide evidence of the different operational knowledge assets used as levers in different industry sectors.

Practical implications - Senior executives and chief financial officers in particular are constantly challenged with making the optimum investment decisions given their budget constraints. The model offers a tool for developing and evaluating different resource allocation decisions based on an organization's strategic intent. In addition, the model can be useful in evaluating merger and acquisition decisions. In evaluating target companies the model can be used to identify the core capabilities or competency areas that the target company is leveraging and assess the impact or integration potential for the acquiring company.

Originality/value - This is the first study in the field of IC that has adopted the use of formative indicators in specifying operational knowledge asset constructs. Previous research has focused on developing models with the use of proxy measures as reflective indicators. Therefore the emphasis so far has been on scale development. The use of formative items in this study fills both the business need and theory gap to understand better the causal relationships that exist between work and knowledge assets.
\end{abstract}

Keywords Knowledge management, Intellectual capital, Business performance, Resource allocation, Mathematical modelling

Paper type Research paper
Model for resource allocation 


\section{TLO}

14,4

346

\section{Introduction}

There are many different intellectual capital (IC) models (Sveiby, 2001) that try to articulate the link between knowledge assets and business performance. The majority of them provide an effective high-level taxonomy of intangibles, which primarily anchor around three components:

(1) human capital;

(2) structural capital (SC); and

(3) customer capital (CC).

These categories can be useful at the strategic level in terms of identifying the competence areas of the organization and determining strategic objectives accordingly. In addition, the components of these models have been focused on surrogate measures such as operational, financial or even knowledge-based metrics that contribute to IC valuation as a single component (Powell, 2002). The usefulness of these models can be enhanced if practitioners at the operational level have a language that is sufficiently granular to enable them to understand and manage the intangible factors of production that contribute to IC valuation. For the purposes of this research study, the term "knowledge assets" will be used to describe intangible factors of production at the operational level.

Overall, there is a lack of a fundamental and coherent understanding of the operational knowledge assets that people leverage to drive IC and business performance. A recent Mercer report showed that:

- 92 percent of Chief Financial Officers agree that human capital (HC) determines customer satisfaction;

- 82 percent said that $\mathrm{HC}$ determines profitability; and

- 72 percent believe that $\mathrm{HC}$ influences innovation.

However, 84 percent of the respondents above indicated that they do not explicitly understand what actually drives returns from $\mathrm{HC}$ investments (Mercer Human Resource Consulting and CFO Research Services, 2003).

The scope of this paper is on the operational knowledge assets that human capital leverages to drive IC and business performance. The purpose of this study is two-fold:

(1) to develop a business model that shows the impact of operational knowledge assets on IC components and business performance; and

(2) to use the model to show how operational knowledge assets can be prioritized in driving resource allocation decisions.

\section{Literature review}

The recent productivity of academic research in the fields of KM (knowledge management) and IC (intellectual capital) has been phenomenal (Serenko and Bontis, 2004). However, the distinction between intellectual capital and knowledge management (KM) is still not very clear. IC is static (Sveiby, 1998) and is more concerned with the identification, strategic governance (Wiig, 1997) and exploitation of intellectual assets to create value (Sullivan, 1998; Roos et al., 1998). Consequently, IC draws the attention of external constituents (i.e. financial analysts, shareholders) who 
place emphasis on the valuation of the stock of intellectual assets at a given point in time.

On the other hand, KM is more dynamic and is thus more process oriented. KM addresses the "how" with heavy emphasis on the flow of knowledge (Sullivan, 1998) and thus addresses the operational and tactical elements of the organization (Wiig, 1997). In summary, IC is often referred to as a stock and KM is often referred to as a flow (Bontis et al., 2002). However, both disciplines are still focused on leveraging organizational assets to improve business results.

Wiig (1997) emphasizes that a balanced integration of the two practices (i.e. integration of IC results with $\mathrm{KM}$ activities) is essential for achieving sustainable competitive advantage. However, he continues by observing that organizations today have failed to follow a comprehensive approach, thus focusing on one perspective at the expense of the other.

Stewart (2002) states that the flaw of KM is that it frequently fails to ask what knowledge to manage and why. Overall, Stewart (2002) makes the point that KM resources are wasted because work and knowledge are not linked. Answering questions that reveal the content and structure of knowledge is important in building successful KM programs. For example, Stewart (2002) cites a sample list of questions including:

- What do your customers expect you to know?

- What intellectual materials - facts, bodies of knowledge, technologies, etc. - do you call upon?

- How does work actually get done around here?

In addition, Sveiby (2001) states that the major challenge faced by the IC measurement and KM community relates to the use of proxies such as dollars, euros, and indicators that are far removed from the actual event or action that caused the phenomenon. Similarly, Wiig (1997, p. 403) emphasizes that organizations need to integrate the practices of IC and KM by identifying and explaining "the links which describe causal relationships [...] identify the concepts, mental models and experiential knowledge required to perform intellectual work in order to deliver quality products and services".

Only five published studies (Chen et al. 2004; Bontis, 1998, 2004; Bontis et al. 2000; Bontis and Fitz-enz, 2002) in the extant academic literature have focused on making the link between IC stocks and flows by analyzing the structural relationship of IC components. Results thus far have shown a significant direct link between the IC components and performance, with an explained variance $\left(R^{2}\right)$ ranging between 32 percent and 56 percent. However, the final items used in the partial least squares (PLS) analysis are manifestations of the principal components themselves (i.e. reflective indicators). As such they do not illuminate the content of knowledge assets that contributes to each component. For example, items measuring the effectiveness of human capital such as "bright employees" or "give their best" do not illuminate the knowledge assets that employees are leveraging in performing their daily tasks. According to Bontis (1998), formative indicators are better in implying what items are actually causing or forming the construct. Formative constructs are influenced or formed by several indicators representing different independent phenomenon (Chin, 1998a). For example the latent variable of socioeconomic status is made of four indicators: 


\section{TLO}

14,4

348

(1) education;

(2) occupational prestige;

(3) income; and

(4) neighborhood.

A change in any of the four indicators can influence the socioeconomic status of an individual; the changes of the indicators are independent of each other since they represent different facets of the latent variable. Thus, the relationship between formative variables and their associated indicators is represented with arrows originating from the indicators and pointing to the variables in contrast to the case of reflective variables. However, the theory did not support the use of them, which highlights the inadequacy of current models and at the same time calls for a different approach.

This study complements the scope of previous research above by focusing on the operational level using a List of Operational Knowledge Assets (LOKA) developed by Andreou (2006). LOKA has been developed based on a comprehensive taxonomy of IC components developed (or intangible value drivers) by Green (2004). The taxonomy labeled as Framework of Intangible Valuation Areas (FIVA) proposes seven intangible value drivers that enable business strategy. The drivers include employees, customers, competitors, partners, information, technology, processes and product/services. Zack (1999, p. 126) states that: "Intuitively it makes sense that the firm that knows more about its customers, products, technologies, markets and their linkages should perform better". In identifying the knowledge behind these intangible value drivers, an $8 \times 8$ matrix (Table I) was created depicting performance focus areas from the interaction of the drivers.

Examples of value driver interactions include employee-customer, employee-competitors, and process-technology among others. These interactions are consistent with the value network concept (Allee, 2000) which supports that an enterprise generates value through the knowledge exchanged by its constituents (e.g., customers, suppliers, strategic partners). LOKA in Figure 1 represents a set of performance focus areas and related operational knowledge assets (or critical success factors) that individual workers can leverage to facilitate organizational performance. That is the scope of LOKA is the first row of Table I; that is, the value generated by the knowledge employees' leverage from their interactions with the other value drivers.

Table I.

Performance focus area (PFA) matrix

\begin{tabular}{lllllllll}
\hline & & & & & & & & \\
& Employee & Customer & Competitor & Partners & Information & Technology & Process & $\begin{array}{l}\text { service } \\
\text { Employee }\end{array}$ \\
PFA1 & PFA2 & PFA3 & PFA4 & PFA5 & PFA6 & PFA7 & PFA8 \\
Customer & & PFA9 & PFA10 & PFA11 & PFA12 & PFA13 & PFA14 & PFA15 \\
Competitor & & & PFA16 & PFA17 & PFA18 & PFA19 & PFA20 & PFA21 \\
$\begin{array}{l}\text { Partners } \\
\text { Information }\end{array}$ & & & & PFA22 & PFA23 & PFA24 & PFA25 & PFA26 \\
Technology & & & & & PFA27 & PFA28 & PFA29 & PFA30 \\
Process & & & & & & PFA31 & PFA32 & PFA33 \\
Product/service & & & & & & & PFA34 & PFA35 \\
& & & & & & & & PFA36 \\
\hline
\end{tabular}




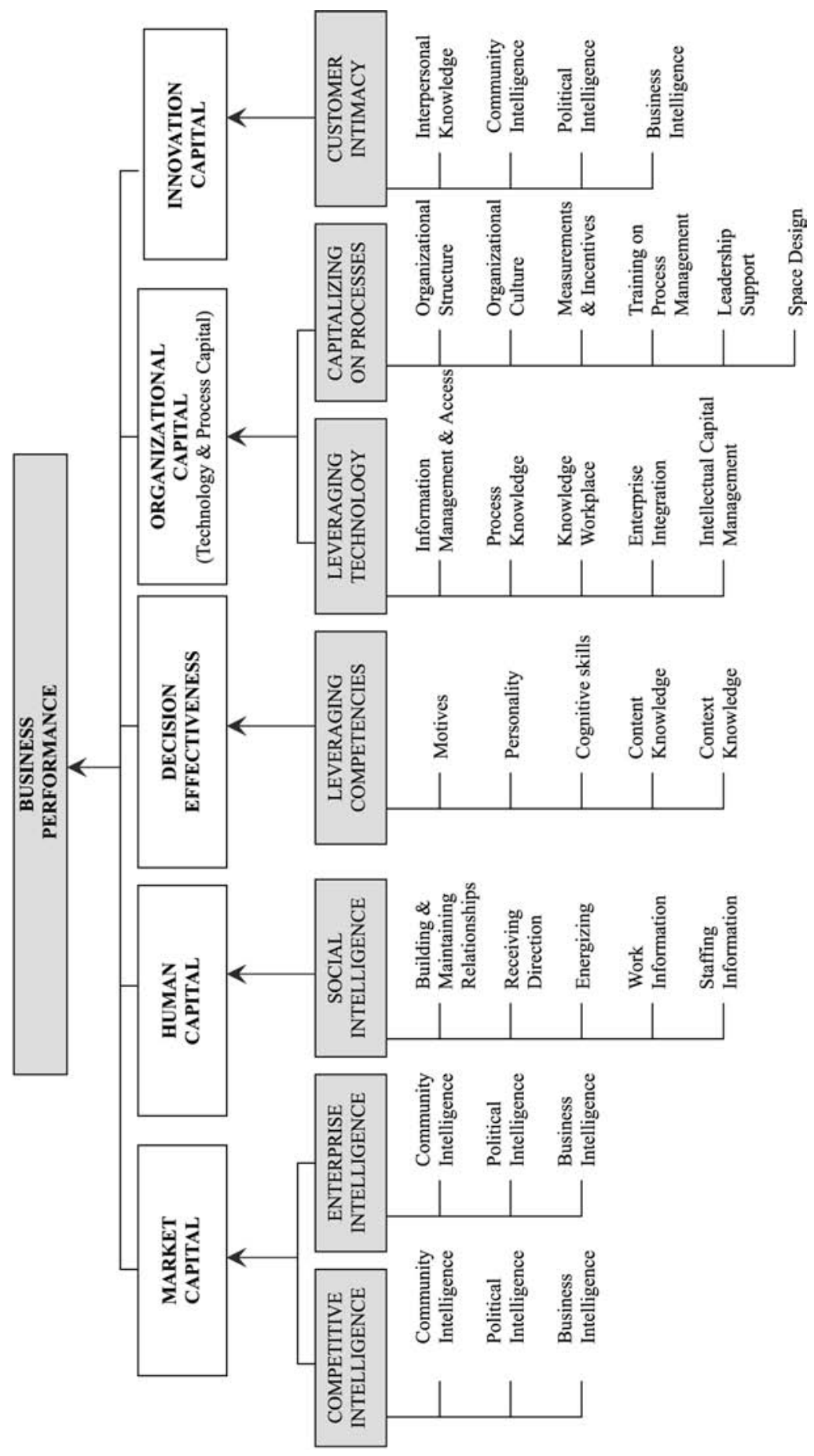

Model for resource allocation

349

Figure 1. List of operation knowledge assets (LOKA) 
TLO

14,4

\section{0}

Performance focus areas represent those operational areas that support the IC components for sustainable competitive advantage. Leveraging the relevant knowledge assets under each area is imperative for achieving strategic objectives. Hunt (1999, p. 144) describes a firm's strategic imperative as: "sustained, superior financial performance $[. .$.$] that [. .$.$] can be achieved through a sustainable competitive advantage$ in the marketplace". Operational knowledge assets represent critical success factors (CSF) that refer to components, contingencies, critical elements, and core competencies among others (Rockart, 1982; Antony and Banuelas, 2002; Andal-Ancion et al., 2003; Hong and Kim, 2002). Rockart's (1979, p. 85) conceptualization of critical success factors is used to describe operational knowledge assets: "the limited number of areas in which results, if they are satisfactory, will ensure successful competitive performance for the organization".

For example, the performance focus area resulting from the interaction of employees and competitors is competitive intelligence. It is conceptualized based on the work of the Society of Competitive Intelligence Professionals (SCIP) and Erickson and Rothberg (2000) as knowledge of what one's competitors are doing by having information regarding their capabilities, vulnerabilities and intentions. In operationalizing "competitive intelligence" one could ask: "What do I need to know about my competitors that add value to my decision-making process and operational efficiency?". Figure 1 lists three knowledge asset domains that can be leveraged to achieve effective competitive intelligence.

Andreou (2006) developed the suggested list of operational knowledge assets through an exhaustive literature review of many management disciplines:

- decision making;

- strategic and operations management;

- human resources and competency management;

- marketing and customer relationship management;

- information technology; and

- stakeholder theory.

The list was validated and revised by collecting and analyzing data from focus groups (for a complete review of the literature and focus group analysis applied in developing LOKA refer to Andreou, 2006). Seven performance focus areas and 31 types of knowledge assets were identified. LOKA represents a list of knowledge assets that employees can leverage to carry the value proposition of their organizations and drive business performance. Therefore, LOKA complements existing IC models that focused on the inter-relationships between the three primary components (i.e. human capital, structural capital and customer capital). The seven constructs representing the different IC and business performance components in Figure 1 (i.e. market capital, human capital, decision effectiveness, technology capital, process capital, innovation capital and business performance) were developed using exploratory factor analysis. Table II lists the 16 items representing the seven constructs comprising IC and business performance. 


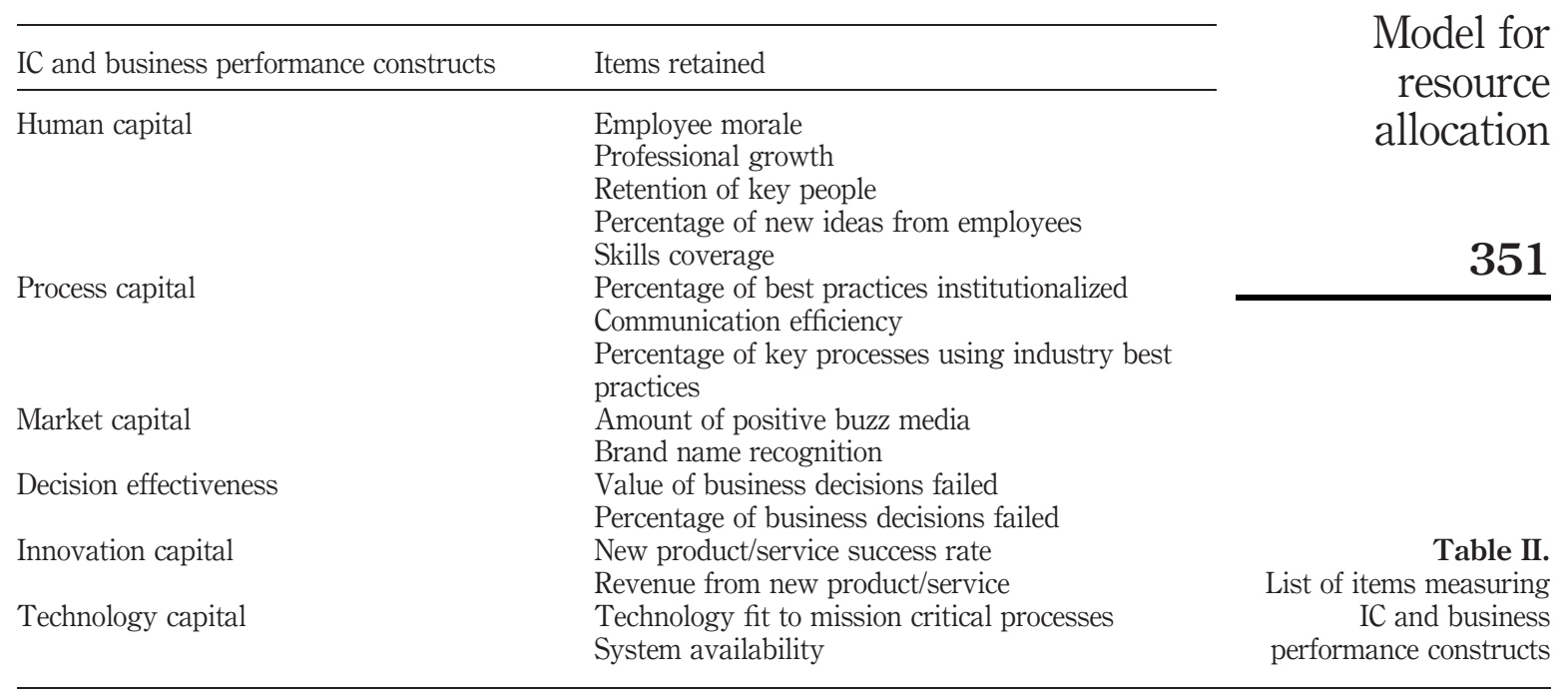

\section{Research design}

The scope of the study focused on business services offered by federal high-tech contractors in the Washington DC metropolitan area. Most of their services are classified under:

- computer system design;

- research and development in the physical, engineering and life sciences;

- guided missile and vehicle manufacturing;

- aerospace manufacturing;

- engineering services, and

- electronic systems.

Eighty-four high-tech federal contractors from the list of "Top 100 Federal Prime Contractors" published by Washington Technology (2005) were selected as the target population. Respondents in the target population were operations managers of business sectors holding positions such as:

- president;

- vice-president;

- director;

- engineering manager;

- operations manager; and

- analyst.

A survey instrument was developed and administered to collect quantitative data to evaluate the relationship between operational knowledge assets and business 
TLO

14,4

352

performance. Survey items were developed for each of the operational knowledge asset categories. The respondents' degree of leveraging each knowledge asset was captured on a six-point Likert scale (i.e. from $0=$ non-applicable to $5=$ very high). Respondents also assessed the average three-year performance of their business sectors relative to the competition on various IC and business performance measures (see Appendix 1). A five-point Likert scale (i.e. from $1=$ significantly lower to $5=$ significantly higher) was used for collecting data on IC and business performance. A copy of the questionnaire items is attached in Appendix 1.

Surveys were distributed to 500 respondents occupied in the different business sectors of their respective organizations. The solicitation was done through:

- an e-mail sent by the research project liaison officer of each company introducing the purpose and application of the research and explaining the organization's interest as a research advocate; and

- mailing of letters to management officers identified on their company's websites.

Respondents interested in participating in the survey were asked to complete a hard copy of the questionnaire that was attached to both the e-mail message and/or the cover letter and were requested to return it in a sealed envelope. A total of 139 replies were received, resulting in a response rate of 27.8 percent. Twelve surveys returned were not usable because they were partially completed (e.g. a whole section of the survey was left out) or the analysis of individual scores indicated that the respondent might have misread, misunderstood, or did not pay attention to the questions asked. Overall, 127 completed surveys were used for data analysis purposes. The control variables of business sector, position and annual revenue of business sector were used to check the sample for any form of response bias according to common practice (Bontis et al., 2002). Figure 2 shows the comparison between the sample and target population for the three control variables. The profile of the business sectors and

\section{Comparing Sample \& Target Population}

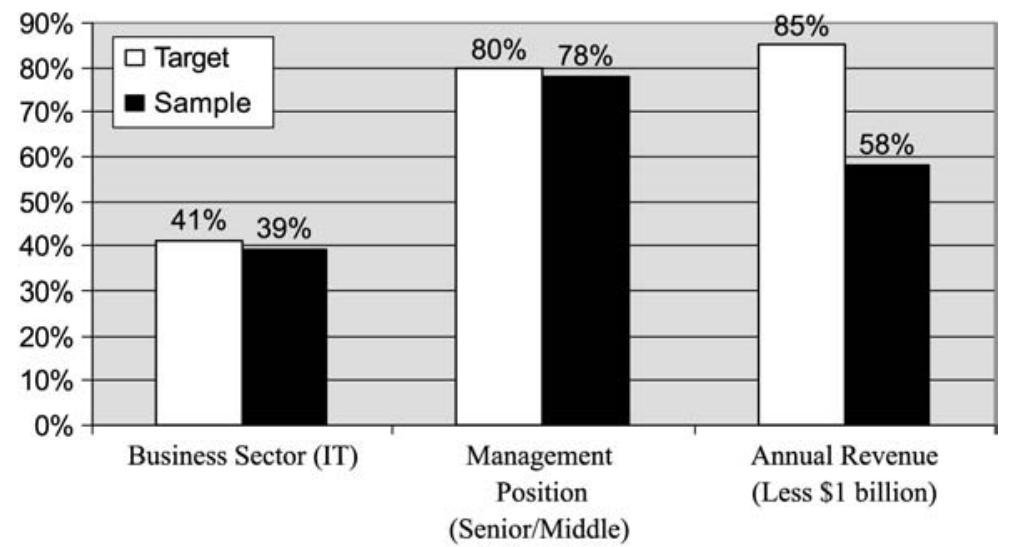

Figure 2.

Sample and target population descriptive statistics

\section{Control Variables}


management positions participated in the survey is representative of the population of interest. Therefore there was no evidence of systematic response bias in the sample.

PLS was used to analyze the data and develop a structural model that optimizes the explained variance of business performance through the interrelationships of operational knowledge assets and IC components. PLS supports variance analysis $\left(R^{2}\right)$ and prediction. Therefore it is useful for exploratory studies characterized by relatively weak a priori theory and where the primary focus is theory development. There are two analysis stages in PLS. First, the measurement model is estimated showing statistics (i.e. loadings) that assess the validity and reliability of variables and their respective constructs. Second, the results for the structural model are reported showing the relationships (i.e. path coefficients) between the constructs and the explained variance. Another advantage of PLS is that it supports model types with both reflective and formative constructs and with varying levels of complexity (i.e. can be used with both small and large samples) (Chin, 1998a, b; Gefen et al., 2000; Chin and Gopal, 1995).

The following rules apply for determining sample size under PLS. The sample size should equal ten times either the number of indicators of the most complex formative latent variable or the largest number of independent variables impacting a dependent variable whichever is greater (Barclay et al., 1995). LOKA has seven first-order formative variables (i.e. performance focus areas) with the most complex one (i.e. capitalizing on processes) comprised of six components. The dependent variable with the largest number of independent variables impacting is business performance. Six constructs (i.e. market capital, human capital, decision effectiveness, technology capital, process capital and innovation capital) impact business performance. According to both rule criteria the required minimum sample size is estimated to be at least 60, which is less than the actual sample used (127).

The stability and the predictive power of the models analyzed with PLS are assessed by looking at the significance and confidence intervals of the PLS parameter estimates. The parameter estimates include:

- the loadings $(\lambda)$ or weights $(\pi$ or $\gamma)$ of the measures to their specified constructs;

- the standardized path coefficients $(\beta)$ between the constructs.

The bootstrapping procedure offered by the PLS-Graph application was used. The number of sample iterations was set to 200. According to Chin (2001) sample iterations of 200 tend to provide good standard error estimates.

\section{Results}

Structural models 1-7 in Figure 3 were used to guide the model generation exercise. Structural models 1-6 show the contribution of the operational knowledge assets under each performance focus area (i.e. LOKA) to their respective IC construct. The IC components shown in Table II were developed to represent each of the performance focus areas. For example, the performance focus area of "leveraging technology" has an impact on the "technology capital" of an organization. Technology capital measured by variables such as "technology fit to mission critical processes" and "low cost of technology deployment" among others. Model 7 investigates the impact of the IC constructs on business performance.

\section{Model for resource allocation}

353 
TLO

14,4

354

Figure 3.

Relationship between operational knowledge assets, IC and business performance constructs

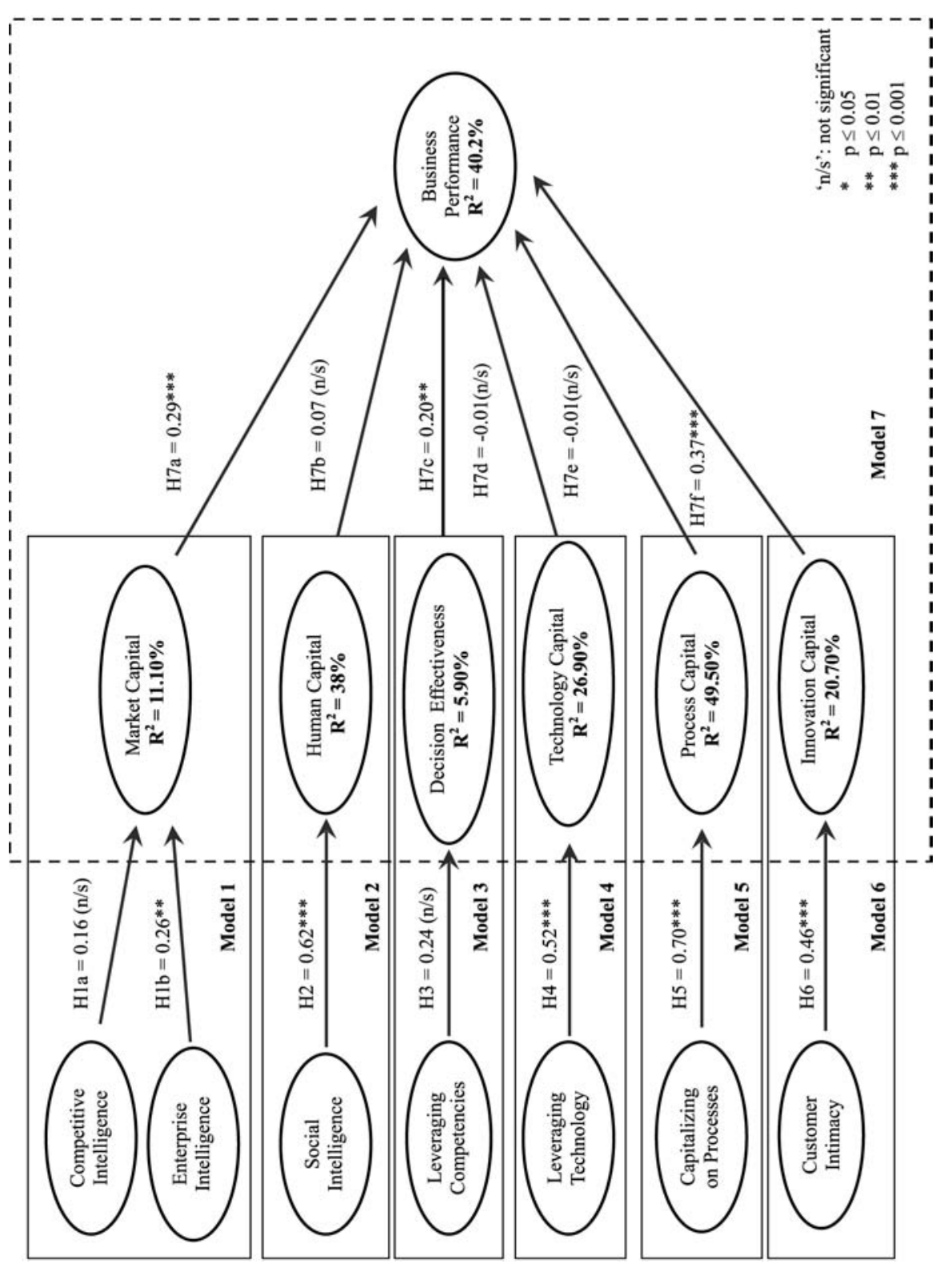


Assessment of each structural model is based on the significance of the path coefficient and the value of explained variance $\left(R^{2}\right)$. The discussion that follows focuses on analyzing each model with the objective of exploring alternative structures that are conceptually sound and satisfy statistical rigor.

There are three significant path coefficients in model 7, suggesting that competitive advantage (as reflected by market capital), innovation effectiveness, and effective decision-making are major catalysts for business performance. However, previous studies discussed above focusing on the relationships of the primary IC components indicated that long-term competitive advantage or sustainability of business performance is dependent upon operational constructs such as "human capital", "process capital" and "technology capital". For example, Chen et al.'s (2004) empirical model illustrates that innovation capital is sustained by human and structural capital. Similarly, Bontis (1998) explains the absence of a statistically strong relationship between human capital and business performance on the mediating effects of structural capital. Therefore model 7 was revised to develop a parsimonious, conceptually sound model with significant path coefficients that supports the intuitive logic depicting the interrelationships between IC constructs and business performance. Figure 4 shows the revised model with the highest explained variance $\left(R^{2}=38.9\right.$ percent) and with all path coefficients statistically significant. In addition the measurement strength of the model was established through validity and reliability estimates. All item loadings were strong, with their values greater than the minimum recommended of 0.7 (Gefen et al., 2000) and were significant with $p$-values less than 0.001. In addition, all items loaded higher on the constructs they measure than on any other construct, thus satisfying discriminant validity. Discriminant validity was also examined through average variance extracted (AVE). AVE measures the amount of variance explained for a given construct by its indicators (Chin, 1998b). AVE for each construct was higher than the minimum required of 0.5 . For discriminant validity the square root of AVE for each construct should be greater than the correlations between each construct. Reliability was also established through calculation of internal consistency $\left(\rho_{\mathrm{c}}\right)$. All constructs had internal consistency higher than the minimum required of 0.7 (Gefen et al., 2000). Tables III and IV show the validity and reliability statistics.

The dynamics of the constructs as presented in Figure 3 are conceptually rational and make intuitive sense. That is, market capital, innovation capability, and decision effectiveness drive the long term performance of an organization. However, these assets need to be continually nurtured and reinforced to be sustained; otherwise they run the risk of eroding. Operational assets such as processes, technology and people can mitigate that risk. For example, bright, skillful, committed people, leveraging the right technologies and processes (i.e. communication, practices, and methodologies) can make the right decisions and create innovative products/services that satisfy the requirements of their customers and create value for their organization. The interaction of people, technology and processes can also create a competitive advantage for the organization as reflected in its brand image in the market place. The strength of the structural model analyzed above was also reinforced by calculating the predictive relevance $\left(Q^{2}\right)$ for the "business performance" construct. $Q^{2}$ measures the ability to recalculate observed variables from the model's parameters (Chin, 1998b). If $Q^{2}>0$ 
TLO
14,4

356

Figure 4.

Relationship between IC and business performance components

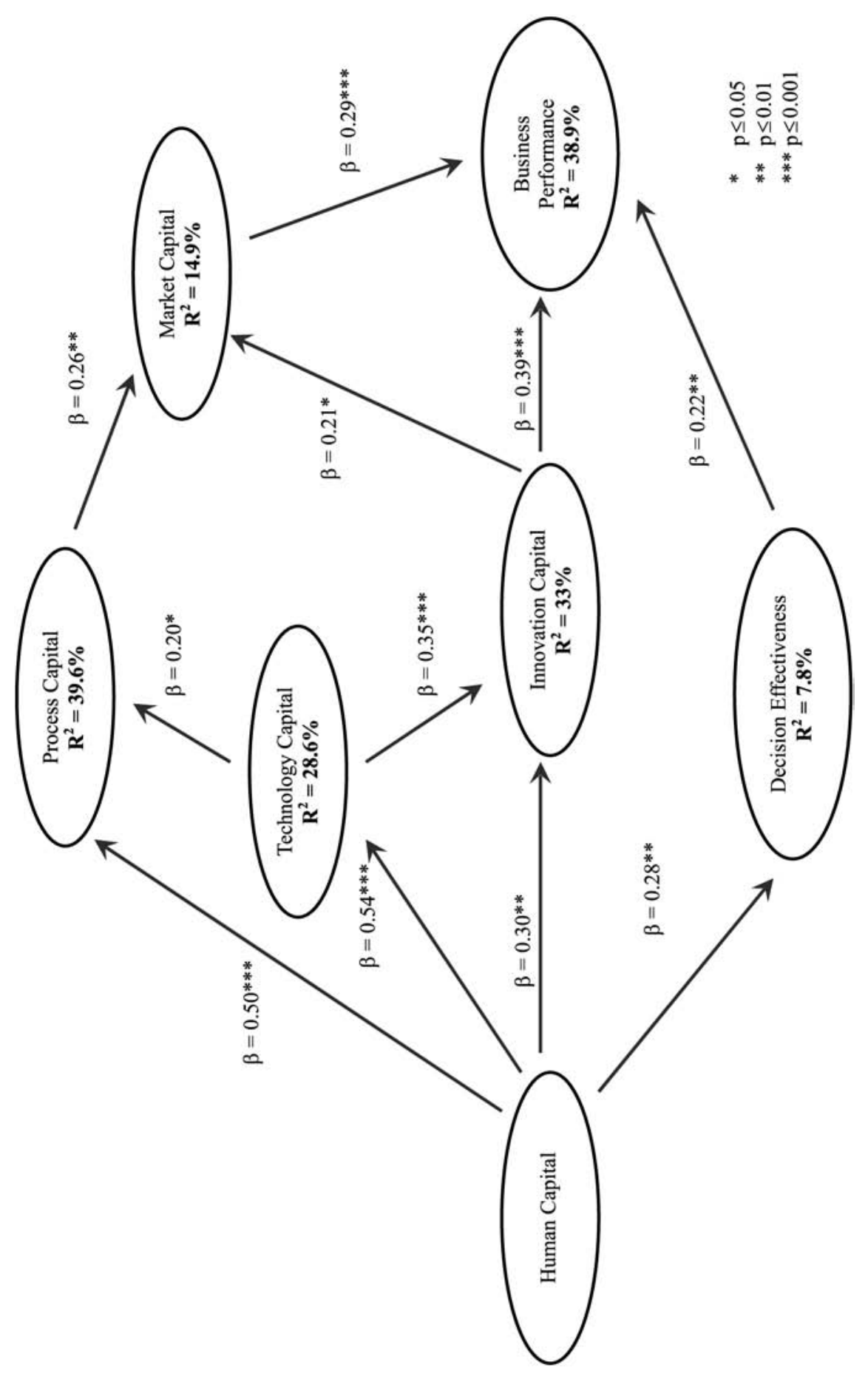




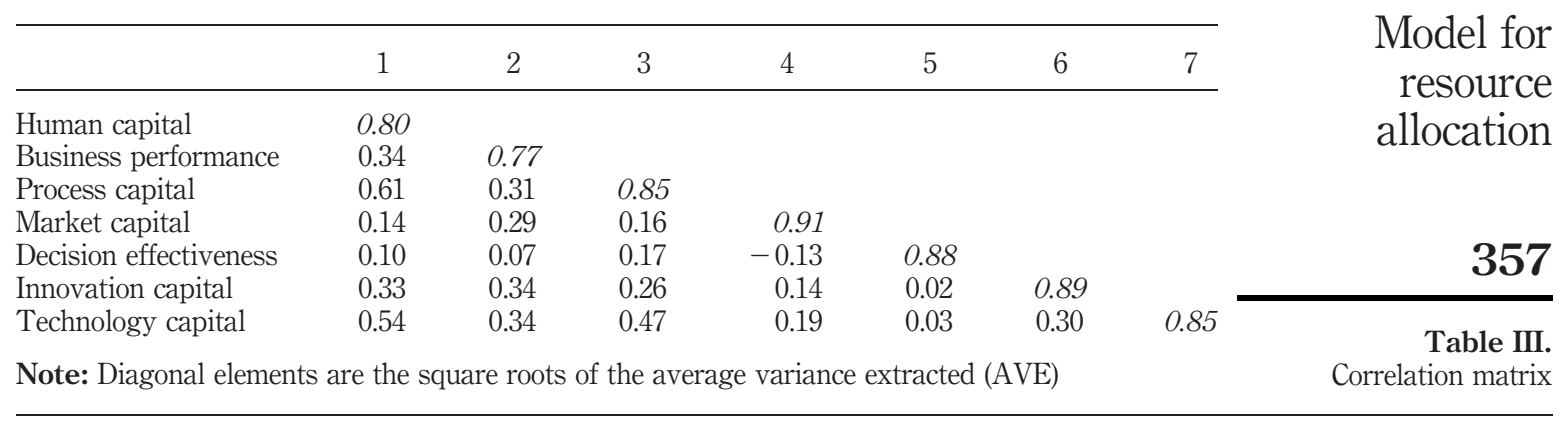

\begin{tabular}{|c|c|c|c|}
\hline Construct & AVE & Internal consistency $\left(\rho_{\mathrm{c}}\right)$ & \\
\hline Human capital & 0.64 & 0.90 & \\
\hline Business performance & 0.59 & 0.90 & \\
\hline Process capital & 0.73 & 0.89 & \\
\hline Market capital & 0.83 & 0.91 & \\
\hline Decision effectiveness & 0.77 & 0.87 & \\
\hline Innovation capital & 0.80 & 0.89 & Table IV. \\
\hline Technology capital & 0.72 & 0.83 & Reliability estimates \\
\hline
\end{tabular}

the model has predictive relevance and vice versa (Chin, 1998b); the $Q^{2}$ statistic for the "business performance" construct was 0.14 .

Having established a valid and reliable model of IC components in explaining business performance, the next question is: "what are the operational critical success factors or knowledge assets that drive these IC components?".

The insignificant path coefficients between some performance focus areas and IC constructs in models 1-6 (see Appendix 2) suggested the exploration of some other relationships. Therefore, each performance focus area was linked to each of the IC constructs. The relationships with the highest path coefficients that were statistically significant and also satisfied conceptual reasoning were chosen. These relationships show the performance focus areas and their related knowledge assets that drive their respective IC components. These relationships were added to the model as shown in Figure 4. Figure 5 represents an extended model showing these relationships.

The business rationale of Figure 5 is explained as follows: the quality of an organization's human capital (i.e. workforce) is determined and enabled by:

- the social environment;

- competent colleagues; and

- competitive intelligence.

Human capital, in turn, supported by effective processes, structures, and technology can make effective decisions and drive innovation. Effective processes result from leveraging enterprise intelligence factors (e.g. unwritten requirements and expectations, required capabilities, policy requirements, stakeholders' vision and direction, resources used by stakeholders, stakeholders' experience, etc.) and process 
TLO

14,4

358

Figure 5.

Extended model

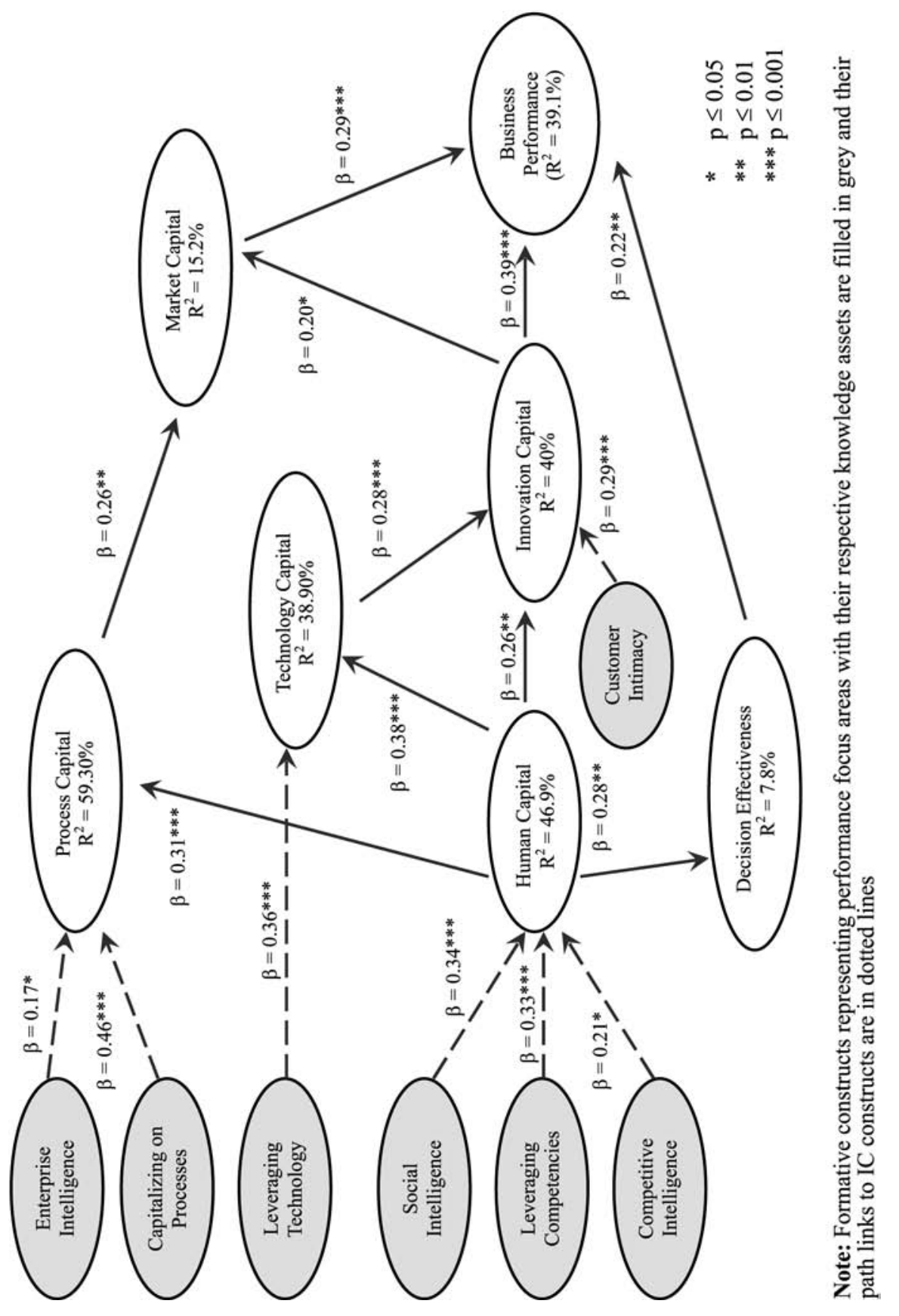


factors (e.g. structure, culture, leadership, training, measurements and incentives, etc). Technology capital is driven by leveraging the appropriate technology functions such as information management and access, process management (e.g. workflow, planning, analysis, etc.), knowledge workplace (e.g. collaboration, communication, expertise location) and enterprise integration (i.e. system and information integration). Innovation capital is also driven by leveraging customers' knowledge, such as their strategies, directions, the business and regulatory environment they operate in, among others. Overall, leveraging the respective knowledge assets under each category (i.e. performance focus area) drives the IC components at the operational level. In turn the operational IC components drive the longer-term intangibles of market capital, innovation capital and decision effectiveness. Market capital, innovative capabilities and effective decisions explain almost 40 percent of the variance in business performance.

It is noted that in the extended model the path between technology capital and process capital is not significant compared to the model in Figure 4, and therefore it is removed. A possible reason for becoming insignificant is that the antecedents representing knowledge assets behind each capital construct provide a better explanation of variance. Looking at the survey instrument thematic descriptors of organizational structure include infrastructure. This could be taken by the respondents to mean technology and systems. So there might be an overlap between the construct of "technology capital" and "organizational structure" which explains why the path from "technology capital" to "process capital" has become insignificant.

Appendix 2 shows the loadings and weightings for the reflective and formative measures respectively in the extended model. All reflective indicators were significant at the 0.001 level, with their associated constructs having high internal consistency and AVE estimates.

By definition formative measures are independent from each other and are expected to have low inter-correlations. Therefore standard measures of internal consistency and reliability used for reflective constructs do not apply for formative constructs. Instead their validity is determined by:

- relative magnitude of their weight and its statistical significance; and

- their ability in explaining other constructs (Chin and Gopal, 1995).

For the purposes of this study they are assessed through their ability to explain the variance of IC components.

Following Diamantopoulos and Winklhofer's (2001) recommendation, the variance inflation factor (VIF) for each formative variable was estimated in assessing multicollinearity. VIF values below 10 are considered acceptable in determining low multicollinearity. The VIF for all variables was below 10, ranging from 1.72 to 5.29.

Table $\mathrm{V}$ shows the relevant operational knowledge assets as determined by the significance of their weight values. Identification of knowledge assets from all categories shows the validity of the constructs formed in representing the performance focus areas.

The (significant) formative measures identified above constitute a list of knowledge assets that are context specific. The overall validity of all the formative measures has to be determined by examining their contribution in a more general context (Mathieson et al., 2001). Therefore all the formative measures were formed into a construct 


\section{TLO}

14,4

Performance focus area
Enterprise intelligence
Capitalizing on processes

360

Leveraging technology

Social intelligence

Leveraging competencies

Competitive intelligence

Table V.

Knowledge assets leveraged by the sample population
Customer intimacy

Notes: ${ }^{* * *} p<0.001 ;{ }^{* *} p<0.01 ;{ }^{*} p<0.05$ (two-tailed)

\begin{tabular}{lc} 
Knowledge assets & Weight \\
\hline Enterprise experience & $0.52^{* *}$ \\
Training on process management & $0.42^{* *}$ \\
Measurements and incentives & $0.37^{* *}$ \\
Leadership support & $0.29^{*}$ \\
Enterprise integration functions & $0.56^{* *}$ \\
Information management and access functions & $0.49^{* *}$ \\
Receiving work information & $0.40^{*}$ \\
Cognitive skills & $0.53^{*}$ \\
Content knowledge & $0.46^{*}$ \\
Motives & $-0.38^{*}$ \\
Competitors' government requirements & $-0.89^{* *}$ \\
Competitors' resources used & $0.69^{*}$ \\
Competitors' marketing strategies & $-0.62^{*}$ \\
Customers' government requirements & $0.45^{* *}$
\end{tabular}

representing the set of resources or knowledge assets which is linked to a general construct. The general construct represents the overall perception as to whether the organization is leveraging the necessary resources to create value. The construct is labeled "resource leverage" Section 3 of the questionnaire had five questions that collected relevant data. Table VI shows the item questions along with their validity and reliability estimates in forming the "resource leverage construct". To check the reliability of the construct, the statistics of item to total correlation were estimated. The fifth question, "Our leverage of the resources that facilitate performance for the business sector is limited", had low item to total correlation (0.25) and therefore was removed from the construct to improve reliability. Cronbach's alpha was 0.86 after removing the weak item.

Figure 6 shows the relationship between the resource construct and the construct of overall leverage perception. It represents a redundancy model (Mathieson et al., 2001). According to Mathieson et al. (2001), a beta coefficient between the formative and reflective construct of 0.8 and above is considered a strong indicator as to the validity of the set of formative measures. Therefore the construct labeled "knowledge assets" is

\begin{tabular}{lccc} 
Items $\left(\rho_{\mathrm{c}}=0.91 ; \mathrm{AVE}=0.71\right)$ & Loadings & Weights & $\begin{array}{c}\text { Significance } \\
(p \text { value })\end{array}$ \\
\hline $\begin{array}{l}\text { There is a coherent understanding of the key factors } \\
\text { that drive performance in our business sector }\end{array}$ & 0.88 & 0.31 & $* * *$ \\
$\begin{array}{l}\text { We have a good knowledge of the key causes that } \\
\text { link work activities to results in our business sector }\end{array}$ & 0.85 & 0.29 & $* * *$ \\
$\begin{array}{l}\text { In our business sector we have access to the } \\
\text { resources that drive performance }\end{array}$ & 0.78 & 0.28 & $* * *$ \\
$\begin{array}{l}\text { In our business sector we know what levers to pull in } \\
\text { order to achieve desired performance }\end{array}$ & 0.85 & 0.30 & $* * *$
\end{tabular}

\section{Table VI.}

Item statistics for measuring resource leverage 
considered complete to represent the pool of resources or knowledge assets leveraged by the organizations. In addition, the set of knowledge assets explains 63.3 percent of the variance of the resource leverage perception. Two formative items representing technology had significant weights with $p \leq 0.05$ :

(1) process knowledge functions; and

(2) intellectual capital management functions.

These two items were not significant within the nomological context of the extended model in Figure 5. This shows the importance of context in assessing the contribution of formative measures. According to Mathieson et al. (2001), the inclusion of non-significant formative measures does not affect the validity of the model's parameters, especially in the absence of multicollinearity. Therefore, non-significant formative items can be retained in the model. In addition, the estimates here are subject to one limitation. According to the sample requirements of PLS a sample size of 400 is required (i.e. ten times the number of items of the exogenous construct). Therefore, the parameter estimates should be interpreted with caution. Future research could focus on collecting more data to reassess the validity of the items and parameter estimates. In addition, in future research it might be better if a general construct is formulated for each asset category. For example, a construct measuring the overall perception of leveraging process factors can be different from a general construct measuring the perception of leveraging technology factors.

In summary, results support the contribution of knowledge assets as antecedents to explaining models of IC components and business performance.

\section{Discussion}

One of the primary applications of the extended model is on making resource allocation decisions. Executives and chief financial officers in particular are constantly challenged with making the optimum investment decisions given their budget constraints. For example, imagine a CFO having ten million dollars to invest this year in different programs that claim to improve the organization's performance. In the context of the organizations surveyed, the three primary areas of knowledge assets that resources could be invested using as a criterion their weight values in absolute terms are:

(1) intelligence on competitor's government requirements;

(2) intelligence on competitors' resources used; and

(3) intelligence on competitors' marketing strategies.

These results are perfectly reasonable given the nature of the sample studied (high-tech federal contractors). All respondents compete for one primary client, which is the US

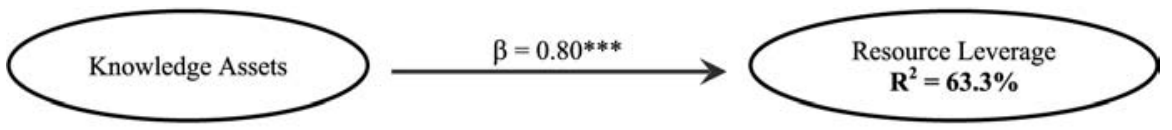

Note: $\mathrm{p}$-value (1-tail): $* * * \leq 0.001$
Model for resource allocation

361 
TLO

14,4

362
Government, and possibly for the same product or service. It would be critical for each of them to have intelligence on each other's resources and relationships with the Government.

Alternatively one could prioritize the knowledge assets to invest in by focusing on the strongest areas of the organization (i.e. looking at the positive weight values). In this case the three areas with the highest positive weight values are:

(1) competitors' resources used;

(2) enterprise integration functions; and

(3) cognitive skills.

These three knowledge asset categories suggest investment in the following three functional areas of the organization:

(1) marketing department;

(2) technology department; and

(3) human resource department.

First, the marketing department can invest money on systems and programs that will collect better competitive intelligence which is necessary for adapting proactively to a turbulent, complex environment (Heinrichs and Lim, 2003). In addition, better competitive intelligence gives the organization a niche in responding to potential disastrous threats or opportunities (Dishman and Pearson, 2003). Second, technology managers can focus their investments in systems that facilitate system and business integration. Enterprise integration is another key driver for developing complex adaptive organizational systems. Its value proposition is that it provides agility and adaptability in responding to change (e.g. customer needs, competition, market condition, etc.) by integrating systems, applications and processes among business partners. As the number of business partners required in competing successfully in a global, flat world, is increasing, investment in systems that support the enterprise of the future is critical. Last, human resource management people could make investments on programs (e.g. recruiting and training) that develop the cognitive skills of their workforce. Cognitive skills include both analytical and conceptual thinking. Both are a must for professionals providing consulting and product solutions in the high-tech sector. Overall the model is very useful in that it can be applied in identifying and monitoring investments in each of the performance focus areas identified and helps organizations to align operational knowledge assets with strategic objectives.

Another practical application of the model is on evaluating merger and acquisition decisions. In evaluating target companies the model can be used to identify the core capabilities or competency areas that the target company is leveraging and assess their impact or integration potential for the acquiring company. For example, a company strong in leveraging process factors (e.g. structures, leadership and space) might be considering acquiring a company that is strong in leveraging technology and personal competencies. The model could be used to simulate the integration of process and human capital factors and their impact on performance.

A third application offered by the results is on identifying cross-leverage opportunities within the organization. The internal periodic measurements of the assets that drive performance could break organizational silos and enable 
cross-functional leverage of knowledge assets. For example, Maccoby (1999) offers a list of qualities that cross-functional team members should have. The list consists of vision awareness, expertise and peer recognition, situational awareness, decision-making boundaries, team skills and collaboration, and the right character traits. These qualities are found in the descriptors of the knowledge assets (i.e. LOKA). For example, one could use the list of operational knowledge assets to create an "architectural blueprint" (Mayo, 2001, p. 198) for each employee that shows their knowledge and capabilities beyond their functional roles.

The results are also useful for IC and KM theory development. Bontis $(1999,2001)$ criticizes the academic field by stating that the measures defining IC and KM are scattered and lack consistency in their form and scope. In addition, he suggests that a common set of definitions through empirical research would help the field to integrate its concepts and principles. Green's (2004) FIVA was a significant step in providing a common taxonomy of intangibles. This study has adopted empirical research through both qualitative and quantitative methods to investigate the assets emerging from the intangible value drivers. The list of seven performance focus areas and 31 knowledge asset categories offers a terminology baseline at the operational level. This baseline has been articulated by the bottom up through the operations people who are dealing with the day-to-day management activities of the organizations. This is a major contribution of the study since research in the field has been driven primarily at the macroeconomic level with emphasis on market valuation and measurement (Powell, 2002). Although at the macro level the concepts and frameworks might differ depending on which discipline one is coming from, (e.g. accounting, finance, marketing, technology, economics, human resource management, education and learning, engineering, etc.), (Marr and Chatzkel, 2004) the assets at the operational and tactical level are more homogeneous in their nature and form. Therefore, the list of operational knowledge assets developed in this study aims at improving the communication about intangibles at the operational level.

There are also some important methodological contributions from this study; that is, the adoption of both qualitative and quantitative research. Qualitative research through focus groups contributed to confirming the theory-based LOKA and the development of the questionnaire items. Quantitative research through exploratory factor analysis contributed to validating the constructs of IC and business performance. In addition quantitative analysis through partial least squares provided a significant statistical measurement and structural model depicting the impact of operational knowledge assets on IC and business performance measures. The role of theory in designing good causality studies is important. Theory contributes to the formulation of the causal model. Model generation involves an iterative process between exploration and confirmation; many models can support the same theory. Therefore, using structural modeling with qualitative data in interpreting causal assertions or models is both a science and an art (Pedhazur, 1997; Gefen et al., 2000). Qualitative research through focus groups is an effective method in investigating and understanding complex phenomena and concepts (Morgan, 1997). The five empirical studies reviewed above did not apply any form of qualitative research. Therefore, this study is pushing the research methods in the field one step further. According to Marr and Chatzkel (2004), the field needs to move forward by adopting more rigorous empirical research methods applied in theory testing. Such methods include 
TLO

14,4

364

quantitative longitudinal studies with large sample sizes applied in specific contexts (i.e. case studies), (Marr and Chatzkel, 2004).

In addition, the study has adopted the use of formative indicators in specifying constructs. As indicated before, predictive models used so far have focused on the use of proxy measures through reflective indicators. Therefore their emphasis was on scale development versus index development. "Index" is used in the sense of developing a list of items that forms causal relationships. The use of formative items fills the business need to understand better the causal relationships that exist between work and knowledge assets (Stewart, 2001a). The contribution of each formative construct identified in this study in explaining the variance of its related IC components is critical in moving the field forward. It is understood that at the strategic level where measurement and valuation being the primary focus proxy measures are more appropriate. However, the findings of this study support a theory of using causal items in explaining phenomena in the IC literature, especially at the operational and tactical level. Therefore the use of formative measures in this study complements the observation made by Bontis (1998) that one has to look at theory to decide the direction of measures. Theory at the operational and tactical level supports the use of formative measures in understanding cause and effect relationships between operational assets and IC proxy measures.

Last, the use of PLS in the KM and IC field is still relatively new. The complex nature of the field makes it a suitable candidate for the application of PLS. PLS is a powerful methodology for exploratory studies and for analyzing complex theory and related models (Gefen et al., 2000). Application of PLS with consistent results among different studies in the field will help the shift towards more rigorous methodologies such as confirmatory research. Such a shift would enable researchers in the field to understand and communicate in a uniform and consistent manner the theory and concepts behind the field of KM and IC.

Furthermore, the study is subject to an important constraint. The business performance measures used (e.g. ROA, profit growth, return on sales, etc.) are based on current accounting practices that do not account for the effect of intangibles. The predictive strength of the model would be better assessed if business performance was measured taking into effect the value of intangibles. For example it would be interesting to test the model on Baruch's list of "smart" companies (Stewart, 2001b) using their intangible valuation as a basis of business performance. Another limitation of the study is the risk of common method bias. The most relevant sources of common method bias to this study are: common rater bias and common scale format. The best method to address common rater bias is to use different respondents for the dependent and independent variables. However, the risk of compromising respondent anonymity and the unavailability of alternative sources of data prevent us from applying an effective measure against common rater bias. Common scale bias was addressed by using different Likert scale anchors for the dependent and independent variables (i.e. operational knowledge assets and IC components and business performance variables, respectively). In addition the use of quasi-objective measures to complement subjective measures controlled for any common method bias. The strong correlation between subjective and quasi-objective measures of business performance give confidence to the absence of any significant common method bias. 


\section{Conclusion}

According to Drucker (1999), the principles of Taylor (1856-1915), the father of scientific management, are found in every management discipline and method, whether called "task analysis", "total-quality management", or "industrial engineering". As discussed above, Taylor's study of manual work was more about knowledge than skill, specifically the knowledge of methods, processes and way things get done. Therefore, the critical challenge of the twenty-first century is how to make the knowledge worker more productive. The answer lies in understanding the knowledge methods - that is, to move from the epistemological definitions and discussion of knowledge and study more thoroughly the methods employed by knowledge workers in performing their tasks. Bontis (1998, p. 72) offers a warning to those who make the task of IC valuation the primary premise for the value proposition of the field by stating: "A formula (for intellectual capital) may never exist [...] examining the processes underlying intellectual capital development may be of more importance than ever finding out what it is all worth". In building models that try to depict relationships between IC and business performance one gains a better understanding of the nature and dynamics of the IC components themselves. For example, one would expect that achieving business performance would also drive human capital. That is, achieving desired results would increase the commitment and morale of the workforce. For example Bontis and Fitz-enz (2002) have found a negative feedback loop between business performance and employee turnover. Improvement in human capital (HC) effectiveness would generate another operating cycle among IC components in driving business performance. Therefore, it makes intuitive sense to expect a feedback loop from business performance back to human capital. This feedback loop represents the endogenous or organic value of the IC field. As Bontis (1998, p. 72) states, this notion "is similar to the idea of deutero learning", that is, understanding the process itself or "learning how to learn".

Stewart (2001a, p. 194) stated: “... there's increasing evidence that the faithful servant isn't just misplacing a spoon here or there but has lost track of some valuable jewels, paid no attention to the furnace and the water heater, and put the place at risk". Therefore what we need to understand is the way of doing business that is dependent on knowledge assets. LOKA and the model presented in this study provide an initial step towards understanding the methods of leveraging knowledge and a step towards better measurement and even disclosure (Bontis, 2003). Surprisingly enough these methods are dependent on the traditional elements of processes, structure, culture, strategy, leadership, measurement and incentives, business intelligence, and customer relationships, among others. The difference is that we need to understand in this new era is the new ways these elements interact within and between organizations. Overall, the results of this study offer a first attempt in providing a common ground for understanding the levers behind IC drivers.

\section{References}

Allee, V. (2000), "Reconfiguring the value network", The Journal of Business Strategy, Vol. 21 No. 4, p. 36.

Andal-Ancion, A., Cartwright, P.A. and Yip, G.S. (2003), "The digital transformation of traditional business", MIT Sloan Management Review, Vol. 44 No. 4, pp. 34-41. 
TLO

14,4

366

Andreou, A. (2006), "An exploratory study to identify operational knowledge assets from intangible value drivers in the high tech sector", DSc dissertation, George Washington University, Washington, DC.

Antony, J. and Banuelas, R. (2002), "Key ingredients for the effective implementation of six sigma program”, Measuring Business Excellence, Vol. 6 No. 4, pp. 20-7.

Barclay, D., Higgins, C. and Thompson, R. (1995), "The partial least squares (PLS) approach to causal modelling: personal computer adoption and use as an illustration", Technology Studies, Vol. 2 No. 2, pp. 285-309.

Bontis, N. (1998), "Intellectual capital: an exploratory study that develops measures and models", Management Decision, Vol. 36 No. 2, pp. 63-76.

Bontis, N. (1999), "Managing organizational knowledge by diagnosing intellectual capital: framing and advancing the state of the field", International Journal of Technology Management, Vol. 18 Nos 5-8, pp. 433-62.

Bontis, N. (2001), "Assessing knowledge assets: a review of the models used to measure intellectual capital”, International Journal of Management Reviews, Vol. 3 No. 1, pp. 41-60.

Bontis, N. (2003), "Intellectual capital disclosure in Canadian corporations", Journal of Human Resource Costing and Accounting, Vol. 7 Nos 1/2, pp. 9-20.

Bontis, N. (2004), "National Intellectual Capital Index: a United Nations initiative for the Arab region”, Journal of Intellectual Capital, Vol. 5 No. 1, pp. 13-39.

Bontis, N. and Fitz-enz, J. (2002), "Intellectual capital ROI: a causal map of human capital antecedents and consequents", Journal of Intellectual Capital, Vol. 3 No. 3, pp. 223-47.

Bontis, N., Crossan, M. and Hulland, J. (2002), "Managing an organizational learning system by aligning stocks and flows", Journal of Management Studies, Vol. 39 No. 4, pp. 437-69.

Bontis, N., Keow, W. and Richardson, S. (2000), "Intellectual capital and business performance in Malaysian industries”, Journal of Intellectual Capital, Vol. 1 No. 1, pp. 85-100.

Chen, J., Zhu, Z. and Xie, H.Y. (2004), "Measuring intellectual capital: a new model and empirical study", Journal of Intellectual Capital, Vol. 5 No. 1, pp. 195-212.

Chin, W.W. (1998a), "Issues and opinion on structural equation modeling”, MIS Quarterly, Vol. 22 No. 1 , p. VII.

Chin, W.W. (1998b), "The partial least squares approach to structural equation modeling", in Marcoulides, G.A. (Ed.), Modern Methods for Business Research, Lawrence Erlbaum Associates, Mahwah, NJ.

Chin, W.W. (2001), "PLS-graph user's guide”, Version 3.0 (unpublished).

Chin, W.W. and Gopal, A. (1995), “Adoption intention in GSS: relative importance of beliefs", Data Base Advances, Vol. 26 Nos 2/3, pp. 42-63.

Diamantopoulos, A. and Winklhofer, H.M. (2001), "Index construction with formative indicators: an alternative to scale development", Journal of Marketing Research, Vol. 38 No. 2, pp. 269-77.

Dishman, P. and Pearson, T. (2003), "Assessing intelligence as learning within an industrial marketing group: a pilot study”, Industrial Marketing Management, Vol. 32 No. 7, pp. 615-20.

Drucker, P.F. (1999), "Knowledge-worker productivity: the biggest challenge", California Management Review, Vol. 41 No. 2, pp. 79-94.

Erickson, S.G. and Rothberg, H.N. (2000), "Intellectual capital and competitiveness: guidelines for policy”, Competitiveness Review, Vol. 10 No. 2, p. 192. 
Green, A. (2004), "Prioritization of sources of intangible assets for use in enterprise balance scorecard valuation models of information technology (IT) firms", DSc dissertation, George Washington University, Washington, DC.

Gefen, D., Straub, D.W. and Boudreau, M.C. (2000), "Structural equation modelling and regression: guidelines for research practice", Communications of the Association for Information Systems, Vol. 4 No. 7, pp. 1-77.

Heinrichs, J.H. and Lim, J.S. (2003), "Integrating web-based data mining tools with business models for knowledge management”, Decision Support Systems, Vol. 35 No. 1, pp. 103-12.

Model for resource allocation

367

Hong, K.K. and Kim, Y.G. (2002), "The critical success factors for ERP implementation: an organizational fit perspective”, Information \& Management, Vol. 40 No. 1, pp. 25-40.

Hunt, S.D. (1999), "The strategic imperative and sustainable competitive advantage: public policy implications of resource-advantage theory", Academy of Marketing Science Journal, Vol. 27 No. 2, pp. 44-159.

Maccoby, M. (1999), "Building cross-functional capability: what it really takes", Research Technology Management, Vol. 42 No. 3, pp. 56-8.

Marr, B. and Chatzkel, J. (2004), "Intellectual capital at the crossroads: managing, measuring, and reporting of IC", Journal of Intellectual Capital, Vol. 5 No. 2, pp. 224-9.

Mathieson, K., Peacock, E. and Chin, W.W. (2001), "Extending the technology acceptance model: the influence of perceived user resources", Database for Advances in Information Systems, Vol. 32 No. 3, p. 86.

Mayo, A. (2001), The Human Value of the Enterprise: Valuing People as Assets: Monitoring, Measuring, Managing, Naperville Nicholas Brealey, London.

Mercer Human Resource Consulting and CFO Research Services (2003), "Human capital management: the CFO's perspective 2003", available at: www.mercerhr.com/ knowledgecenter/reportsummary.jhtml?idContent $=1082490$ (accessed September 9, 2004).

Morgan, D.L. (1997), Focus Groups as Qualitative Research, 2nd ed., Sage Publications, Newbury Park, CA.

Pedhazur, E.J. (1997), Multiple Regression in Behavioral Research: Explanation and Prediction, 3rd ed., Harcourt Brace College Publishers, Fort Worth, TX.

Powell, T.W. (2002), "The knowledge matrix: a proposed taxonomy for enterprise knowledge", in Koening, M.E.D. and Srikantaiah, T. (Eds), Knowledge Management Lessons Learned: What Works and What Doesn't, published for the American Society for Information Science by Information Today, Medford, NJ, pp. 225-37.

Rockart, J.F. (1979), "Chief executives define their own information needs”, Harvard Business Review, March/April, pp. 81-92.

Rockart, J.F. (1982), "The changing role of the information systems executive: a critical success factors perspective", Sloan Management Review, Vol. 24 No. 1, pp. 3-13.

Roos, J., Roos, G., Edvinsson, L. and Dragonetti, N.C. (1998), Intellectual Capital: Navigating in the New Business Landscape (trans. by Roos, J.), New York University Press, New York, NY.

Serenko, A. and Bontis, N. (2004), "Meta-review of knowledge management and intellectual capital literature: citation impact and research productivity rankings", Knowledge and Process Management, Vol. 11 No. 3, pp. 185-98.

Stewart, T.A. (2001a), The Wealth of Knowledge: Intellectual Capital and the Twenty-First Century Organization, Currency, New York, NY. 
TLO

14,4

368
Stewart, T.A. (2001b), “Accounting gets radical”, Fortune, April 16, p. 184.

Stewart, T.A. (2002), "The case against KM”, Business 2.0, February.

Sullivan, P.H. (1998), Profiting from Intellectual Capital: Extracting Value from Innovation, Wiley, New York, NY.

Sveiby, K.E. (1998), "Intellectual capital and knowledge management”, available at: www.sveiby. com/articles/IntellectualCapital.html (accessed April 1, 2004).

Sveiby, K.E. (2001), "Methods for measuring intangible assets", available at: www.sveiby.com/ articles/IntangibleMethods.htm (accessed April 1, 2004).

Washington Technology (2005), “Top 100 Federal Prime Contractors 2005”, available at: www. washingtontechnology.com/top-100/2005/ (accessed December 19, 2005).

Wiig, K.M. (1997), “Integrating intellectual capital and knowledge management”, Long Range Planning, Vol. 30 No. 3, pp. 393-405.

Zack, M.H. (1999), "Developing a knowledge strategy”, California Management Review, Vol. 41 No. 3, p. 125.

\section{Further reading}

Beames, C. (2003), "Managing your human capital: the ultimate determinant of organizational performance?", white paper, WRDI Institute Pty Ltd, West Melbourne.

Johnson, J.T., Griffeth, R.W. and Griffin, M. (2000), "Factors discriminating functional and dysfunctional salesforce turnover", The Journal of Business \& Industrial Marketing, Vol. 15 No. 6, pp. 399-415.

Kampmeier, C. (1997), “Customer intimacy: pick your partners, shape your culture, win together", Journal of Management Consulting, Vol. 9 No. 3, pp. 75-7. 


\section{Appendix 1}

SECTION 1 - EVALUATING BUSINESS PERFORMANCE

1.1. Please compare the average three-vear performance of your business sector to that of your competitors for each of the following items: (Circle one of the five alternatives using the scale below)

Scale: 1 = significantly lower; 2 = slightly lower; $3=$ equal; $4=$ slightly higher; $5=$ significantly higher

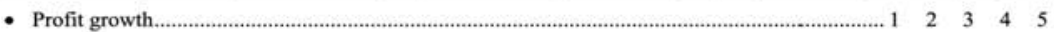

- Return on assets ................................................................................................................ 1

- Revenue growth................................................................................................................. $1 \begin{array}{cccccc}2 & 2 & 4 & 5\end{array}$

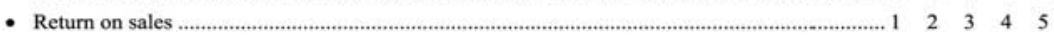

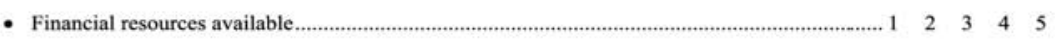

- Rate of increase in market share .......................................................................................... 1

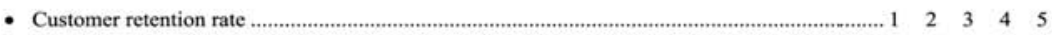

- Customer acquisition cost (i.e. average cost of attracting new customers) ................................ $1 \quad 2 \quad 3 \quad 4 \quad 5$

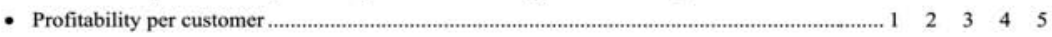

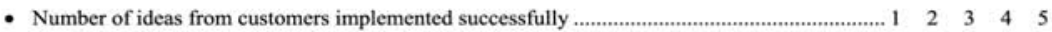

- Product or service fit of purpose.......................................................................................... $1 \quad 2 \quad 3 \quad 4 \quad 5$

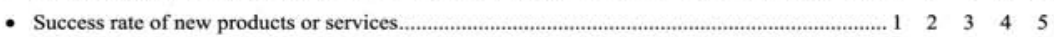

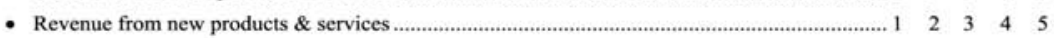

- Research \& Development spending ...................................................................................... $1 \begin{array}{cccccc} & 2 & 3 & 4 & 5\end{array}$

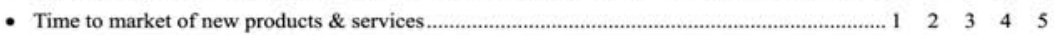

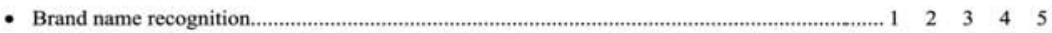

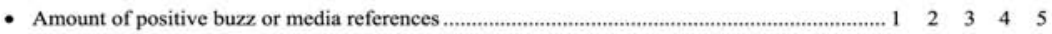

- Average expenditure on compliance to regulator (i.e. government, labor unions) requirements $\begin{array}{llllll}1 & 2 & 3 & 4 & 5\end{array}$

- Number of ideas received by external stakeholders (e.g. universities, business partners) ........... $1 \begin{array}{lllllll}2 & 3 & 4 & 5\end{array}$

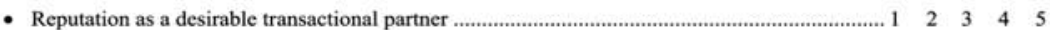

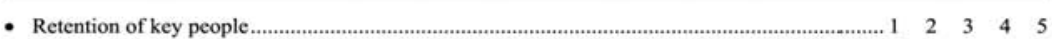

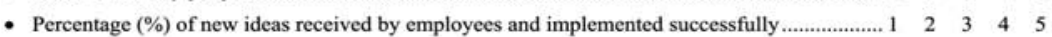

- Skills coverage (i.e. the average number of people in the company that have a required skill)... $\begin{array}{llllllll} & 2 & 3 & 4 & 5\end{array}$

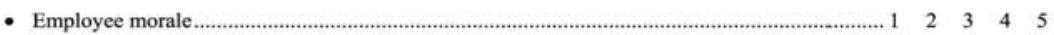

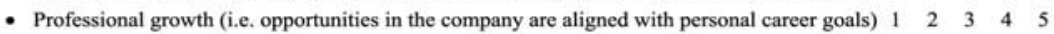

- Percentage (\%) of business decisions failed................................................................................ $1 \quad 2 \quad 3 \quad 4 \quad 5$

- Value of business decisions failed ........................................................................................... $1 \quad 2 \quad 3 \quad 4 \quad 5$

- Percentage (\%) of strategic objectives achieved …................................................................ $1 \quad 2 \quad 3 \quad 4 \quad 5$

- Communication efficiency (i.e. average time to discover \& implement best industry practices) $\begin{array}{lllllll}1 & 2 & 3 & 4 & 5\end{array}$

- Percentage (\%) of best practices or lessons learned institutionalized across the business sector. $1 \quad 2 \quad 3 \quad \begin{array}{llllll}2 & 2 & 5\end{array}$

- Technology fit to mission critical processes..................................................................... $1 \quad 2 \quad 3 \quad 3 \quad 4 \quad 5$

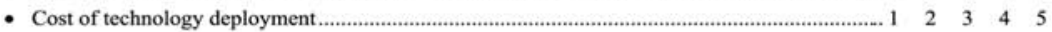

- Value of IT systems discontinued over the last three years................................................... $1 \quad 2 \quad 3 \quad 4 \quad 5$

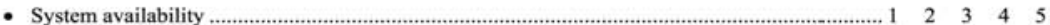




\section{TLO}

14,4

- Percentage $(\%)$ of key processes that used industry best practices

- Infrastructure relocation speed (i.e. time required to redeploy resources to respond to new demands) ..................................... $1 \quad 2 \quad 3 \quad 4 \quad 5$

- Lead time required to respond to new demands .................................................................... $1 \quad 2 \quad 3 \quad 4 \quad 5$

- Percentage $(\%)$ of occasions that critical resources were available when required..................... $1 \quad 2 \quad 3 \quad 4 \quad 5$

1.2. With reference to the performance data available to you, please indicate the average three year performance of your business sector in your organization on each of the four measures listed below: (Circle one of the five alternatives next to each item)

\begin{tabular}{|c|c|c|c|c|c|c|c|}
\hline 1 & 2 & 3 & 4 & \multicolumn{4}{|l|}{5} \\
\hline Negative & $0 \%-10 \%$ & $10 \%-20 \%$ & $20 \%-30 \%$ & \multicolumn{4}{|c|}{$>30 \%$} \\
\hline Profit growth.......... & & & ............ 1 & 2 & 3 & 4 & 5 \\
\hline - Return on assets ................. & & & ......... 1 & 2 & 3 & 4 & 5 \\
\hline - Revenue growth...... & & & .............. 1 & 2 & 3 & 4 & 5 \\
\hline - Return on sales ..................... & ste & & $\ldots \ldots \ldots \ldots 1$ & 2 & 3 & 4 & 5 \\
\hline
\end{tabular}

1.3. Please indicate your level of confidence in responding to performance questions in section 1.1 above?

$\square$ Very Strong $\square$ Strong $\square$ Moderate $\square$ Low $\square$ Uncertain

\section{SECTION 2 - LIST OF RESOURCES}

The statements below represent possible resources (i.e. information, capabilities, skills, experience, networks, ideas, personal attributes, motives, and understanding) that an individual worker might be leveraging (i.e. enable him/her) in facilitating business performance.

As a representative of the business sector for which you are now working please indicate the degree of leveraging the resources listed under each category: (Circle one of the six alternatives next to each statement

Scale: $0=$ Non applicable; $1=$ very low; $2=$ low $3=$ moderate $4=$ High; $5=$ very high

\begin{tabular}{|c|c|c|c|c|c|}
\hline \multicolumn{6}{|l|}{ Category 1 - Leveraging SOCIAL INTERACTIONS with colleagues: } \\
\hline $\begin{array}{l}\text { - Building strong relational bonds } \\
\text { (e.g. trust, shared experiences, networking opportunities, shared interests) .............................. }\end{array}$ & 1 & 2 & 3 & 4 & \\
\hline $\begin{array}{l}\text { - Receiving Direction } \\
\text { (e.g. advise, guidance, mentoring, informal feedback, recommendations, ideas) ................... } 0\end{array}$ & 1 & 2 & 3 & 4 & \\
\hline - Receiving stimulation (e.g. excitement, motivation, strength, re-assurance, validation),........ 0 & 1 & 2 & 3 & 4 & \\
\hline $\begin{array}{l}\text { - Receiving work information } \\
\text { (e.g. subject matter knowledge, know-how, lessons learned, office politics).......................... } 0\end{array}$ & 1 & 2 & 3 & & \\
\hline - Receiving staffing information (e.g. experience required, job opportunities, experts) ............0 & 1 & 2 & 3 & & \\
\hline
\end{tabular}

\section{Category 2 - Leveraging PERSONAL COMPETENCIES:}

- Motives (e.g. hidden agendas, willingness, feelings) ............................................................ $0 \begin{array}{llllll}0 & 1 & 2 & 3 & 4 & 5\end{array}$

- Personality characteristics (e.g. ego, curiosity, passion) ...................................................... $0 \begin{array}{lllllllllll}0 & 1 & 3 & 4 & 5\end{array}$

- Cognitive skills (e.g. synthesizing, analyzing, organizing, communication, creativity) ....... $0 \begin{array}{lllllllll}0 & 1 & 2 & 3 & 4 & 5\end{array}$

- Content knowledge (e.g. domain knowledge, methodologies, education, training).............. $0 \begin{array}{lllllll}0 & 1 & 2 & 3 & 4 & 5\end{array}$

- Context knowledge (e.g. where \& when it applies, purpose, who benefits) .......................... $0 \begin{array}{llllll}0 & 1 & 2 & 3 & 4 & 5\end{array}$

\section{Category 3 - Leveraging CUSTOMER INTERACTIONS}

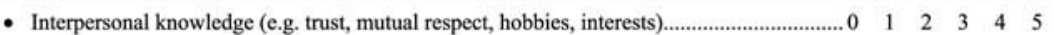

Figure A1. 


\section{Category 4 - Leveraging TECHNOLOGY for:}

- Information management and access functions

(e.g. ease of access to information, semantic analysis, availability of information).

- Process knowledge functions

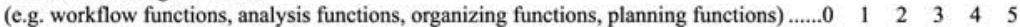

- Knowledge workplace functions

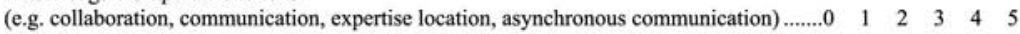

- Enterprise integration functions

(e.g. information integration, system integration, job/project integration)

$\begin{array}{llllll}0 & 1 & 2 & 3 & 4 & 5\end{array}$

- Intellectual capital management functions (e.g. training, learning).

$\begin{array}{llllll}0 & 1 & 2 & 3 & 4 & 5\end{array}$

Model for resource allocation

Scale: $0=$ Non applicable; $1=$ very low; $2=$ low $3=$ moderate $4=$ High; $5=$ very high

\section{Category 5 - Leveraging PROCESS FACTORS:}

- Organizational structure

(e.g. documented processes/procedures, industry standards, infrastructure, roles, rules)....... $0 \begin{array}{llllll}0 & 1 & 2 & 3 & 4 & 5\end{array}$

- Organizational culture (e.g. norms, practices, values)

$\begin{array}{llllll}0 & 1 & 2 & 3 & 4 & 5\end{array}$

- Measurements and incentives (e.g. consequences, benefits, feedback, outcomes) ............... $0 \begin{array}{llllllll}0 & 1 & 2 & 3 & 4 & 5\end{array}$

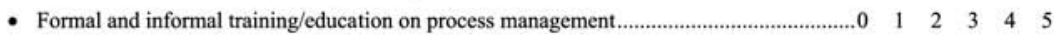

- Leadership support (e.g. process owners, authority, process champions, facilitators).......... $0 \begin{array}{lllllllll}0 & 1 & 2 & 3 & 4 & 5\end{array}$

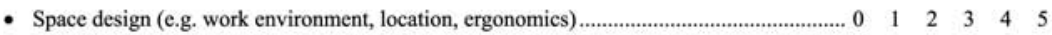

\section{Category 6 - Leveraging INFORMATION:}

Instructions: Please indicate the degree of leveraging the information listed in the left hand column as it relates to: (a) your business sector, (b) your customers and (c) your competitors:

(Circle one of the six alternatives in each cell)

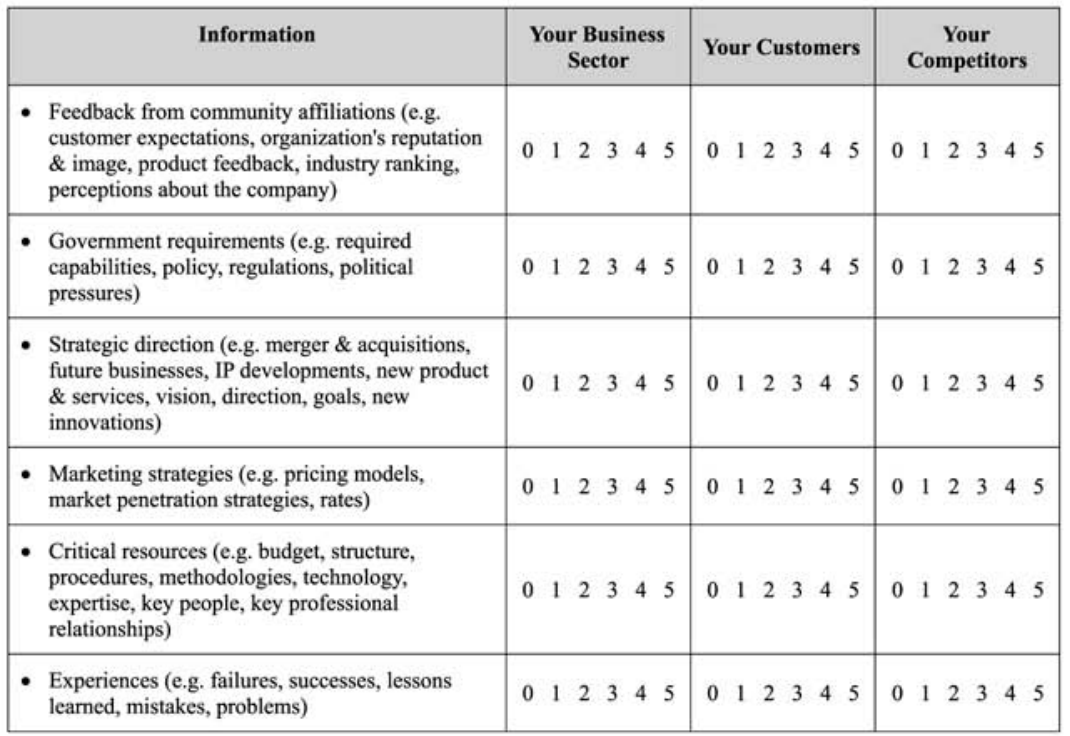




\section{TLO}

14,4

372

Figure A1.

\section{SECTION 3 - PERCEPTION OF LEVERAGING RESOURCES}

As a representative of the business sector for which you are now working, please indicate your level of agreement or disagreement with each statement by circling one of the five alternatives next to each statement.

\begin{tabular}{|ccccc|}
\hline 1 & 2 & 3 & 4 & 5 \\
\hline $\begin{array}{l}\text { Strongly } \\
\text { disagree }\end{array}$ & $\begin{array}{l}\text { Moderately } \\
\text { disagree }\end{array}$ & $\begin{array}{c}\text { Neither } \\
\text { disagree nor agree }\end{array}$ & $\begin{array}{c}\text { Moderately } \\
\text { agree }\end{array}$ & $\begin{array}{l}\text { Strongly } \\
\text { agree }\end{array}$ \\
\hline
\end{tabular}

- There is a coherent understanding of the key factors that drive performance in our business sector.....

- We have a good knowledge of the key causes that link work activities to results

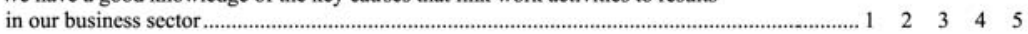

- In our business sector we have access to the resources that drive performance ............................. $1 \begin{array}{llllll}1 & 2 & 3 & 4 & 5\end{array}$

- In our business sector we know what levers to pull in order to achieve desired performance ...... $1 \begin{array}{lllll}1 & 2 & 3 & 4 & 5\end{array}$

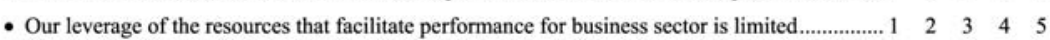

\section{SECTION 4 - RESPONDENT \& BUSINESS SECTOR PROFILE}

Please answer all questions in this part by checking the appropriate box next to the selected answer. Please check only one box for each question.

$\begin{array}{lll}\square \text { Information Technology } & \square \text { Security Systems } & \square \text { Electronic Systems } \\ \square \text { Mission Systems } & \square \text { Business } & \square \text { Software Development } \\ \square \text { System Integration } & \text { Solutions/Consulting } & \square \text { Technical Support and Training } \\ \square \text { Space Technology } & \square \text { Air or Marine } \\ \square \text { Communication Systems } & \square \text { Aeronautics } & \square \text { Other, (please specify): }\end{array}$

4.2. Position: $\square$ Vice President $\square$ Director $\square$ Program Manager $\square$ Manager

$\square$ Other, (please specify):

4.3. Annual revenue of business sector: $\square$ Less than \$1billion $\square$ \$1billion - \$5billion $\square$ More than \$5billion

4.4. Number of employees in the business sector: $\square$ Less than $5000 \quad \square 5000-10000 \quad \square$ More than 10000

4.5. Gender: $\square$ Male $\square$ Female

4.6. Age: $\square$ Under 30 $\square 30-39 \square 40-49 \quad \square 50-59 \square$ Over 59 


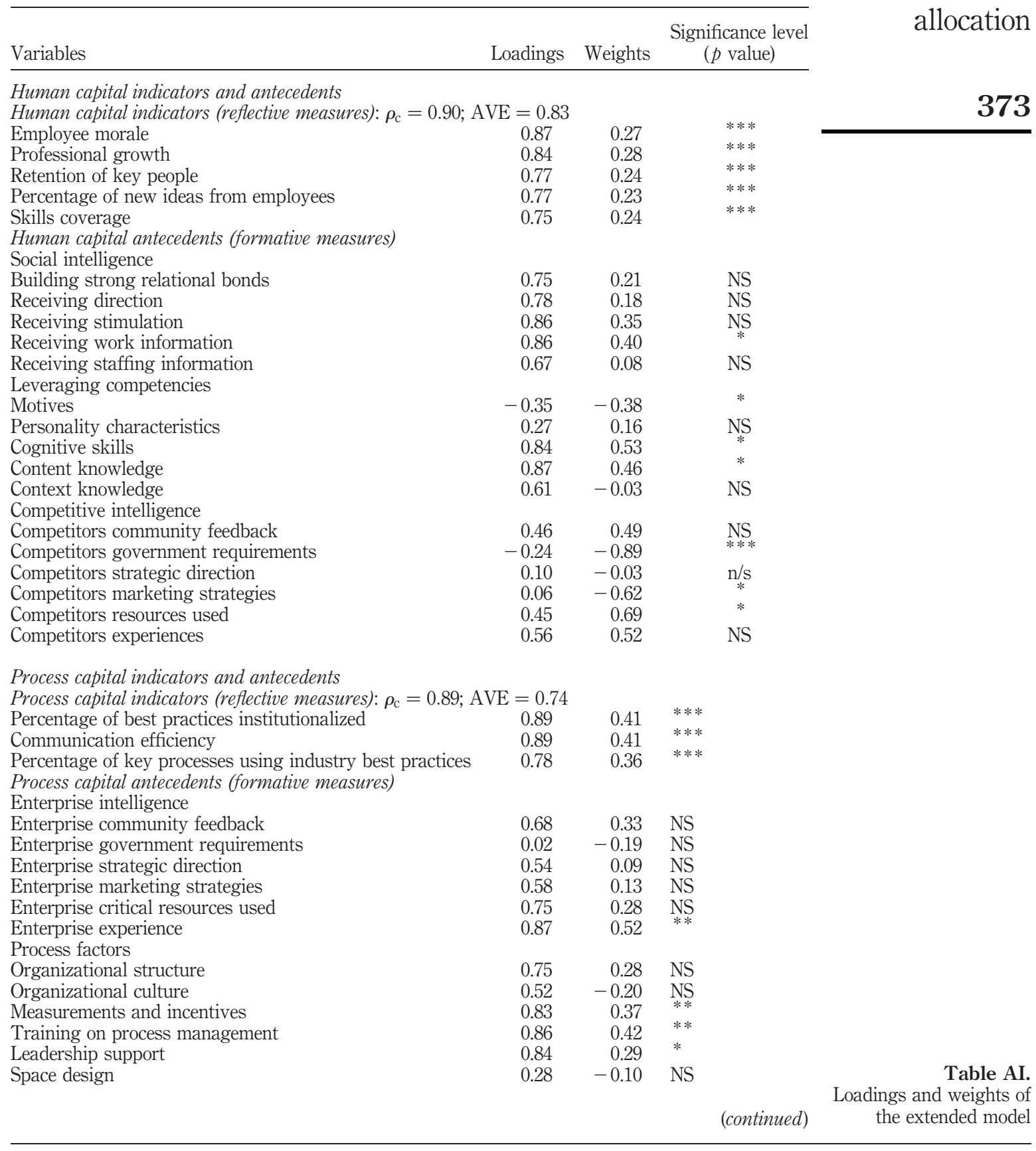


Technology capital indicators and antecedents

Technology capital indicators (reflective measures): $\rho_{\mathrm{c}}=0.84 ; \mathrm{AVE}=0.72$

Technology fit to mission critical processes

374

System availability

Technology capital antecedents (formative measures)

Information management and access functions

Process knowledge functions

Loadings Weights

( $p$ value)

Knowledge workplace functions

Enterprise integration functions

Intellectual capital management functions

$\begin{array}{crr}\text { AVE }=0.72 & & * * * \\ 0.90 & 0.69 & * * * \\ 0.78 & 0.47 & \\ & & \\ 0.82 & 0.49 & * * \\ 0.61 & -0.27 & \text { NS } \\ 0.72 & 0.11 & \text { NS } \\ 0.87 & 0.56 & * * \\ 0.74 & 0.25 & \text { NS }\end{array}$

Innovation capital indicators and antecedents

Innovation capital indicators: $\rho_{\mathrm{c}}=0.89 ; \mathrm{AVE}=0.81$

New product/service success rate

Revenue from new product/service

$\begin{array}{lll}0.91 & 0.58 & * * * \\ 0.88 & 0.53 & * * *\end{array}$

Innovation capital antecedents (formative measures) - customer intimacy

Interpersonal knowledge

Customer community feedback/intelligence

Customer political intelligence

$\begin{array}{lll}0.65 & 0.29 & \text { NS }\end{array}$

Customer strategic direction

$\begin{array}{lll}0.65 & 0.32 & \text { NS } \\ 0.58 & 0.45 & *\end{array}$

Customer marketing strategies

$0.58 \quad 0.45$

$0.59 \quad 0.16 \quad \mathrm{NS}$

Customer resources used

0.50

0.43

0.17

$\begin{array}{rr}0.17 & \text { NS } \\ -0.16 & \text { NS }\end{array}$

Customer experience

$0.68 \quad 0.35 \quad$ NS

Decision effectiveness indicators: $\rho_{\mathrm{c}}=0.87 ; \mathrm{AVE}=0.77$

Value of business decisions failed

Percentage of business decisions failed

Market capital indicators: $\rho_{\mathrm{c}}=0.91 ; \mathrm{AVE}=0.83$

Amount of positive buzz media

Brand name recognition

Business performance indicators: $\rho_{\mathrm{c}}=0.90 ; \mathrm{AVE}=0.59$

Profit growth

Return on sales

$\begin{array}{lll}0.81 & 0.40 & * * * \\ 0.94 & 0.71 & * * *\end{array}$

Return on assets

Revenue growth

Rate of increase in market share

Profitability per customer

$\begin{array}{lll}0.93 & 0.59 & * * * \\ 0.89 & 0.49 & * * * \\ & & \\ 0.83 & 0.22 & * * * \\ 0.81 & 0.22 & * * * \\ 0.80 & 0.23 & * * * \\ 0.80 & 0.23 & * * * \\ 0.68 & 0.19 & * * * \\ 0.70 & 0.22 & * * *\end{array}$

Table AI.

Notes: $p$-values are two-tailed for formative weights and one-tailed for loadings of reflective measures; ${ }^{* *} p<0.001 ;{ }^{* *} \mathrm{p}<0.01 ;{ }^{*} p<0.05$; NS, not significant

\section{Corresponding author}

Nick Bontis can be contacted at: nbontis@mcmaster.ca

To purchase reprints of this article please e-mail: reprints@emeraldinsight.com Or visit our web site for further details: www.emeraldinsight.com/reprints 